and one that is unfortunately rather refractory to change. Indeed it is so concrete and robust that you feel there must be a readily and well-defined cause. Perversely, the book's message is that there isn't.

John W. Galloway (formerly at the Cancer Research Campaign) is at the Nuffield Foundation, 28 Bedford Square, London WC1B 3EG, UK.

\section{Rewriting the future}

\section{Walter Gratzer}

Great Mambo Chicken and the Transhuman Condition: Science Slightly Over the Edge. By Ed Regis. Viking: 1991. Pp. 199. £16.99.

The Virgin and the Mousetrap: Essays in Search of the Soul of Science. By Chet Raymo. Viking: 1991. Pp. 308. \$18.95.

THE trouble with progress, as the philosopher said, is that it goes on too long. Ed Regis's excellent vade-mecum to the wilder shores of science gives evidence enough to chill your gizzard for the truth of this proposition. Here you will learn about plans for hijacking and populating comets as our world grows less friendly and more crowded, for moving the Earth into a more hospitable orbit by extending solar sails into space to gather thrust from sunlight and, since vaulting ambition may as well o'erleap itself as not, for transforming the system of sails into a nuclear fusion engine, powerful enough to move the Sun itself. A Harvard professor of physics develops a grand unified theory (or GUT) that he believes to fit the facts at last and finds to his ineffable dismay that it implies the instability of the proton; so in a space of $10^{31}$ years atomic matter will collapse like an underdone soufflé. Gloom and despair take possession of him - but never fear, for Freeman Dyson is at hand with a wheeze: all we need do is to generate a huge, cosmic energy flux (easily encompassed by turning a lot of matter into radiation) that will split open the closed Universe like a seed-pod, and then the collapse will be offset by endless expansion in another direction. (Dyson anyway does not hold with the idea of a closed Universe, which gives him, he says, a feeling of claustrophobia.)

\section{Achieving immortality}

Or we could tinker a little with our DNA and rewire ourselves for life at the nearabsolute zero of outer space. We might even learn to hibernate, and then our periodic moments of consciousness would seem, thanks to our arrested metabolism, like an eternity. James Thurber had a similar apprehension: "I'm sixty-three", he wrote to his publisher when he was sixty-three "and I guess that puts me in with the geriatrics, but if there were fifteen months in every year, I'd only be forty-three."

You may of course take the view that the future, when Earth is but a star that once had shone, can be left for your grandchildren to trouble themselves about, but, in California at least, the opinion seems to have taken hold that death is discretionary. There is, for instance, the alternative course of having your head detached and preserved in liquid nitrogen until such time as the trifling problems that still stand in the way of growing a disease-proof body from the neck down have been overcome. Cephalariums, full of bubbling vats of heads, already clutter the western seaboard. Some 25 years ago, as Regis reminds us, a paper appeared in this very journal with the good news that a cat brain, brought to room temperature after six months in the freezer, at once began to put out electrical signals little different from those generated by the living cat.

But stay: if you wait until you die or rather deanimate, in the language favoured by the believers - before suffering your head to be frozen, then you may not be in your mental prime when the last trump sounds and you rise from the nitrogen. The jazz musician Eubie Blake remarked on his hundredth birthday that if he had known he was going to live so long he would have looked after himself better. Well, no need to lose sleep over such dilemmas because less conservative thinkers, such as Professor Moravac, will tell you that freezing heads is yesterday's technology. The reason, you ask? Why, because nanotechnology is around the corner, and 50 years from now, perhaps less, there will be molecular robots to surge through your brain, neuron by neuron, reading off stored electrical signals. A year or two's work will suffice to 'download' the contents of your brain onto disc, and then you may live for eternity, in a body with the form, materials and colours of your choice, experiencing by way of appropriate inputs all the sensations you desire, from the perpetual orgasm that is said to feature prominently on the Muslims' agenda for paradise, to irrigating your tonsils with bounteous tides of Chateau Yquem. Nor will your immortality be tried by earthquakes or nuclear explosions, for backup copies of your disc - of you - will repose in safe places around (or beyond) the world.

If progress depends, as George Bernard Shaw suggested, on the unreason- able man, you will find the whole galère in Regis's pages. Here is virtuoso science writing of rare vigour and mastery; and for those who enjoy being frightened it eclipses Mary Shelley and her Gothic nightmares. If, however, you find Regis's supercharged style too wearing in large doses, then perhaps Chet Raymo is your man. He is a professor of astronomy and columnist in the Boston Globe, and the essays gathered in his new volume are polished, civilized and literate discourses on a wide spectrum of scientific topics.

\section{Selfish genes}

Raymo is captivated by the night sky and enchanted with the Escherichia coli to which we are hosts - on so generous a scale indeed that your gut contains, as he calculates, as many as would stretch from Boston to San Francisco. He ranges from Aristarchus and the astronomy of the ancients to selfish genes and the anthropology of the Yanomano Indians of the Amazon, who slaughter each other with no compunction in the interests of sex; homicidal males are rewarded by more wives and many more progeny than pacifists. Are these, Raymo wonders, behavioural genes in action?

Raymo mourns the passing of Rube Goldberg, whose concerns, it seems, transcended those of our nearest British counterpart, Heath Robinson (the man who devised such aids to good living as a machine for the removal of gravy stains from gravel drives). For Goldberg warned against the "gadget-strewn paths of civilisation", among which Raymo numbers nuclear power stations and the monstrous products of the Star Wars programme. There are 21 essays in this collection, all of them cunningly crafted and a pleasure to read, even if here and there the social concern (not to say the PC usage) is laid on a touch too liberally. Raymo is drawn to the philippics of Chargaff, whose apocalyptic visions of a society in thrall to the new genetics find little resonance in the imaginations of other biologists. And you may also stub your toe on an occasional abomination such as "person year" (it followed for me a recent sighting in this country of a ploughperson's lunch); but perhaps one can blame such lapses on a malign subeditor.

Walter Gratzer is in the MRC Muscle and Cell Motility Unit, King's College, Drury Lane, London WC2B 5RL, UK.

\section{Spring Books}

Nature's next review supplement will be Spring Books, which will appear in the 16 April 1992 issue. 